AFRICAN

\title{
Enduring silk ties
}

\author{
by Mandira Bagwandeen* \\ Salamanca Group \\ Cape Town, South Africa
}

\begin{abstract}
Due to China's growing energy needs that stem from its unrelenting drive for economic development, Beijing stresses the importance of maintaining a continuous supply of energy, particularly oil, to maintain its impressive economic growth. However, seeing as China's domestic resources are unable to satisfy its projected future oil demands, the Chinese government realise that, barring significant domestic oil discoveries, their dependency on oil imports, particularly from the Middle East, will continue to increase. As such, Chinese efforts to enhance relations with Iran have mainly stemmed from China's search for energy resources, an opportunity to create a diverse portfolio of overseas market shares, and the desire to exert political influence in the Middle East. Yet, not all credit can be given to Beijing for establishing links with Tehran as Iranian officials have, by advertising the country as a reliable energy source and key strategic partner in the Middle East, managed to gain China's attention and advance Sino-Iranian relations.
\end{abstract}

* Mandira Bagwandeen is a Junior Analyst at Salamanca Group, specialising in political and country risk with regards to the Asia Pacific region. She holds a Masters in International Relations from the University of Cape Town where she focused her MA thesis on China's continued energy interests with Iran in light of the international sanctions regime direct against Tehran for its nuclear ambitions. This article is, in part, drawn from her thesis, "Will Iranian Oil Still Fuel China: An Analysis of Beijing's Stance on International Sanctions Against Iran". 


\section{Introduction}

Chinese efforts to enhance relations with Iran have mainly stemmed from China's (People's republic of China, PRC) search for energy resources, an opportunity to create a diverse portfolio of overseas market shares, and the desire to exert political influence in the Middle East. Yet, not all credit can be given to Beijing for establishing links with Tehran as Iranian officials have, by advertising the country as a reliable energy source and key strategic partner in the Middle East, managed to gain the PRC's attention and advance Sino-Iranian relations. Additionally, aside from acknowledging Tehran's crucial role in the energy market, Beijing also recognises Iran's vital geostrategic location and its potential to be an energy transport base between the Middle East, Central Asia, and Europe (Mackenzie, 2010:i). Due to the multi-dimensional and ever-changing nature of Sino-Iranian relations, it would be impossible to cover every facet of Beijing-Tehran ties in this paper. Therefore, my analysis will focus on the more prominent aspects of the relationship that ties Beijing and Tehran together despite the international pressure placed on China to implement measures to further isolate Iran for its overtly defiant nuclear activities. This paper will analyse the Sino-Iranian relationship from three points of view, namely: trade, energy and geostrategic reasoning. These three factors have been chosen as, based on the literature reviewed, they appear to be the "glue" that binds these two countries together.

\section{Background: Sino-Iranian ties}

The development of Sino-Iranian relations stems from a gradual expansion of ties between China and the Middle East. The birth of this relationship is traced back to the second century BCE when the Han Dynasty of China opened up the Silk Road and established trade with the Parthian Empire. Although official diplomatic relations were established in 1971, Iran kept China at a distance as the United States of America (US) pressured Tehran to limit its interaction with communist Beijing. However, before his overthrow in 1979, Shah Mohammad Reza Pahlavi sought to improve relations with China as mutual concern over Soviet actions in Asia edged the PRC and Iran to achieve greater co-operation. Yet, relations with China were 
again strained when revolutionary leader Ayatollah Ruhollah Khomeni (successor to the Shah), in rebellion against the Union of Soviet Socialist Republics (USSR) and US, supported a foreign policy that was, "neither West nor East." However, Khomeni's suspicions of China had to be revised as Iran's isolation and war with Iraq forced Tehran to cooperate a little more on certain issues with Beijing. The Islamic Republic had come to perceive that China could be used as a counterbalancing mechanism against the USSR and the US, thus providing Iran with much needed leverage on the international stage (Dorraj and Currier, 2008:68). Tehran's new outlook on China suited Beijing's global political agenda as it provided the Chinese with a gateway to pursue their territorial ambitions in Iran and, more importantly, the greater Middle East (Harold and Nader, 2012:3).

The endurance of the Sino-Iranian relationship is attributed to shared interests and similar international political outlooks. The survival of these ties illustrates that both these nations value political pragmatism, strategic thinking, and economic dealings (Douglas, Nelson and Schwartz, 2006:6). However, past grievances against Western hegemony have also played a part in shaping both nations' contemporary outlooks on global politics. With memories of "victimisation" and "vulnerability" at the hands of Western imperialists etched deep into their psyche, Beijing and Tehran continue to protest against Western imperialism and hegemonic behaviour (Baker, 2010:22). As a result, both countries distrust the US and frequently criticise Washington's policy of liberal interventionism as "imperialist" and "hegemonic" (Fite, 2012:7). By acknowledging their historical lineage of having once been "great civilisations", Beijing and Tehran draw inspiration from this narrative to reassert their great power statuses ${ }^{1}$. This essentially fuels China's, "foreign policy goals of a multi-polar world, free of US hegemony, where regional powers play the dominant role within their respective spheres of influence." (Baker, 2010:22). In this regard, Beijing and Tehran's ambitions have remained quite similar.

Even though the commonalities between China and Iran portray a grounded relationship, "when push comes to shove", Beijing has, on various occasions, demonstrated that it is willing to side-line Iran in favour of remaining in comity with the US. This was demonstrated when China acknowledged calls from Washington to 
abandon nuclear co-operation with Iran in 1997. Although Iran disapproved of China's actions, the Ayatollahs realised that it was still in Tehran's best interests to continue working with the Chinese on economic and political issues. Thus, it is by means of such flexibility that the Chinese and Iranians have created a durable, albeit limited, relationship that continues to persist under straining conditions (Baker, 2010:22).

Although the PRC views Iran as a potential partner for limiting US advancements in the Middle East, Beijing is not overly reliant on Tehran for its energy needs, economic development or national security. This is demonstrated by China's globally dispersed sources of oil as well as its substantial oil imports from other Middle-Eastern nations, most notably Saudi Arabia. On the other hand, because of Iran's small number of allies and shunning of the US, Tehran has come to rely heavily on Beijing for vital diplomacy, economic, military and technological assistance. Though China's dependency on Iran is minimal, Sino-Iranian relations have nonetheless enhanced Beijing's capacity to become a vital player in MiddleEastern issues. Aware of how sanctions have heightened the Islamic Republic's vulnerability, Beijing is exploiting Iran by utilising its increasing isolation from the international community to demand Iranian oil at discounted prices. Despite such exploitive demands, Tehran is not willing to dismiss the PRC, as China provides the Islamic Republic with vital diplomatic cover in the international arena. Even though Beijing's relationship with Tehran (an international pariah) may tarnish its image as a "responsible stakeholder" and threaten Sino-US relations, China has nonetheless demonstrated an unusual support for Iran (Douglas, Nelson and Schwartz, 2006:2).

\section{Trade}

In 1979 both nations undertook drastic reforms that laid the building blocks for their present day economic and political relationship (Morris, 2012:2). For Iran, the Islamic Revolution and subsequent hostage debacle led to the deterioration of Tehran's relationship with the West as it was faced with economic sanctions and diplomatic isolation. Whilst Beijing, under Deng Xiaoping, implemented marketbased reforms that were followed by a rise in Gross Domestic Product (GDP) growth 


\section{AFRICAN \\ EAST-ASIAN \\ AFFAIRS \\ THE CHINA MONITOR}

which subsequently led to the ascendance of China as an international force.

Sino-Iranian economic relations have grown steadily. This is demonstrated by the level of trade between the two nations increasing from US\$ 400 million in 1994 to more than US\$ 36 billion in 2012 (Jun and Lei, 2010:43; Dickey and Ighani, 2014). Although economic exchanges were first limited to military purchases by Iran, trade exchanges between Beijing and Tehran have primarily advanced through general trade and dealings in oil-gas. Both nations have hosted various conferences that promote bi-lateral trade and economic co-operation. However, energy is, without question, the main pillar upholding Sino-Iranian economic ties. Due to China's energy demands, bi-lateral trade in fuel resources increased. In addition to rising energy trade, bi-lateral trade in other goods also increased - with the total of non-oil trade reaching US\$ 13 billion in 2014 (Kredo, 2014). Aware of Iran's vast energy resource endowments, Beijing and Tehran have signed various energy deals worth millions of dollars. However, unlike China who mainly views Iran as an energy source and another market for Chinese goods, the Iranians highly value Chinese patronage. The PRC has come to be indispensable to the Iranian economy as it is considered to be an important energy customer, a source of technological knowledge, and a major investor in a variety of Iranian sectors (Gentry, 2005: 115).

Though energy trade dominates Sino-Iranian relations, it has become evident that both nations are interested in expanding economic dealings to incorporate various other sectors. In efforts to expand the Sino-Iranian relationship beyond energy, the two nations established the Chinese-Iranian Joint Commission on Economic, Trade, Scientific, and Technical Co-operation in 1993 (Gentry, 2005:114). This keen interest in diversifying relations became particularly evident in 2005 when Beijing expressed interest in strengthening labour ties between the two nations as well as the possibility of initiating co-operation with regards to aerospace ventures (Gentry, 2005:117). Furthermore, a signed aluminium deal worth US\$ 1 billion significantly demonstrated China's interests in diversifying its relations with Iran (Gentry, 2005:114). China's desire to dabble in different Iranian sectors was again demonstrated at the 2009 Iran-China Economic Co-operation Conference, where many Chinese companies finalised negotiations and signed agreements to improve 
Iranian infrastructure and the country's mining and construction industries (FarrarWellman and Frasco, 2012). In the wake of sanctions issued against the Islamic Republic, China displayed its keenness to expand its interests in the country when Beijing signed a US\$ 20 billion agreement in May 2011 to boost bi-lateral cooperation in Iran's industrial and mining sectors (Harold and Nader, 2012:10).

The Iranian market is considered to be extremely advantageous for China as its natural resources, massive market, strategic location and educated workforce are advantageous factors that have enticed Beijing to engage with Tehran (Vakil, 2006:54). This is echoed by the estimated 250 Chinese companies involved in a variety of projects or retailing in low-cost consumer products in Iran in 2006 (Calabrese, 2006:6). Moreover, due to the positives of trading with Iran, the two countries have announced that they plan to more than double their annual bi-lateral trade from US\$ 30-US\$ 40 billion to US\$ 100 billion by 2016 (Harold and Nader, 2012:10). China's growing economic influence and the effects of sanctions have altered Iran's trading patterns - Tehran has become increasingly dependent on China both as a market and as a source of consumer and industrial goods (Salvin, 2011:1). This plays to Beijing's advantage in terms of foreign direct investment (FDI). Due to the Islamic Republic's strained relations with the West, Iran, in terms of FDI, offers China little competition. Improvements in Chinese-Iranian commercial dealings led China to surpass the European Union (EU) in 2009 to become Iran's largest trading partner, with a bi-lateral trade volume estimated at more than US\$ 21 billion (Mackenzie, 2010:6).

Although the Sino-Iranian economic relationship has evolved to become highly robust, China and Iran have, "yet to fully exploit their economic potential in various [other] spheres" as the regulatory framework underpinning this relationship requires substantial improvements (Jun and Lei, 2010:6). It has been suggested that the SinoIranian economic relationship could be enhanced with the signing of a customs agreement and the co-ordination of import and export regulations between the two nations (Morris, 2012:3). In addition, due to financial and banking obstacles hindering deals from moving forward, China and Iran need to establish a legal arbitration board for bi-lateral disagreements (Jun and Lei, 2010:43). Nevertheless, 
Iran continues to be a key piece in China's foreign economic-energy puzzle.

\section{Energy}

As OPEC's (Oil Producing Export Countries) second largest oil exporter, Iran produces 3.7 million barrels of crude oil per day and is ranked as the world's fourthlargest oil producer (Fite, 2012:10). Furthermore, the country has oil reserves collectively estimated at 155 billion barrels and gas reserves at 33 trillion cubic metres (Fite, 2012:10). Thus, it is not surprising that energy driven China has developed a keen interest in Tehran's energy sector.

Although energy in the form of liquefied natural gas (LNG) has provided a second energy link with Iran, Iranian crude is still the main attraction. Ever since China's first purchase of Iranian oil in 1974 under the Shah's regime, the PRC's oil imports from Iran have grown substantially. Iranian crude accounts for approximately 10-15 of China's total oil imports (Swaine, 2010:4). In 2009 the PRC surpassed Japan to become Iran's top oil customer and in the first half of 2014 it imported 630,000 barrels per day (bpd) - up 48 per cent from the previous year (Lai, 2007:525; Mackenzie, 2010:5; Dickey and Ighani, 2014).

Although the percentage of oil imported from Iran is miniscule when compared to Saudi Arabia and Angola, the Chinese have calculated reasons for importing Iranian oil. Crude oil from Iran not only assists in meeting rapidly increasing Chinese consumption demands, it also helps contain rising import expenses as the sour crude oil (sulphur-rich) found in Iran is comparatively cheaper than sweet crude oil (carbon-rich) (Calabrese, 2006:7). Moreover, access to Iranian oil is gaining importance as Iran provides China with an opportunity to access its oil reserves without competition from Western oil companies (Coskun, 2009:184). Iran is also one of the few Middle-Eastern states that permit China to carry out business in upstream sectors (Hongtu, 2010:50). By being amongst a few Middle East countries that allow Chinese NOCs (National Oil Companies). to carry out upstream ventures, this demonstrates that Tehran is using its energy reserves to strengthen its partnership with Beijing (Gentry, 2005:115-116). Chinese NOCs have also shown a strong interest in downstream developments with more than one hundred Chinese 
companies operating in Iran helping to develop the local metros, ports, airports, and oil and natural gas facilities (Chubin, 2010:65).

Despite Iran barring foreign oil companies from concession agreements and restricting them to "buy back" contracts, Chinese NOCs, unlike many other international oil companies, are not deterred by Tehran's approach to dealing with overseas energy firms (Chubin, 2010:14). China's increasing focus on the Iranian energy sector is demonstrated by the 166 Chinese companies that attended the Iranian Oil Show in 2011, as opposed to the one hundred firms that attended in 2010 (Harold and Nader, 2012:10). Moreover, aside from signing numerous energy agreements, Iran has also formed a joint oil and gas committee with China to advance energy co-operation. Apart from purchasing Iranian crude oil and gas, Beijing (after Japan's withdrawal from deals due to US pressure) has, by securing the massive Azadegan and Yadvaran oil and gas fields, become a formidable player in Iranian upstream operations (Harold and Nader, 2012:11).

Although China has acquired numerous Iranian fuel agreements, Iran's energy sector has presented Beijing with various challenges. Tehran traditionally restricts foreign ownership of its hydrocarbon resources and, due to this, China has been provided with limited opportunities to acquire equity in Iranian oil (Harold and Nader, 2012:22). Like its Western and Japanese counterparts, Chinese investors are prone to becoming frustrated with Iran's approach to drafting contracts and business dealings, as possible ventures usually involve continuous rounds of back and forth negotiations and unimplemented business deals (Harold and Nader, 2012:22). Nevertheless, such obstacles have not hindered China from filling the void that sanctions have created in Tehran's energy sector. By viewing the pull out of Western companies as an opportunity to gain a stronger foothold in the Iranian energy sector, the Chinese have seized this opening by signing various energy deals, particularly during 2005 to 2010, worth an estimated US\$ 120 billion (Morris, 2012:3). Investments of note include a US\$ 40 billion deal to update the Iranian petroleum refining industry, a US\$ 2 billion Sinopec Group agreement to develop the Yadavaran oil field and an additional US\$ 70 billion in assistance directed towards the development of the Yadavaran oil field in exchange for 10 million tons of LNG 
from Iran (Morris, 2012:3).

Despite fortifying Sino-Iranian relations with economic-energy agreements, due to Iran's outdated energy infrastructure analysts are still left with technical difficulties in terms of deciphering how successfully energy agreements are being implemented towards meeting China's energy needs (Budike, 2010:86). Stemming from the numerous energy contracts that have been initiated between the two nations, the Islamic Republic has subsequently been provided with cover to weather sanctions that target its energy sector. However, the "life jacket" that Beijing provides Tehran's energy sector can easily be revoked. Due to, the challenges and potential political backlash linked with conducting business in Iran, most Sino-Iranian agreements are in the, "form of non-binding memoranda of understanding which are easily revocable in the event of political, economic, or internal instability" (Morris, 2012:3).

Taking into consideration the damage that UN sanctions and uni-lateral measures have inflicted on Iran's economy, Tehran views Beijing as a lifeline now more than ever. China is considered to be a strong economic partner that is capable of providing the crucial investment and technology that is need for Iran's economic development. In 2014, China raised its budget for Iranian infrastructure projects from US\$ 25 billion to US\$ 52 billion (BBC News, 2014). Beijing's vested interests in Tehran's energy sector are vital as Iran lacks the necessary expertise and capital to modernise its declining energy industry, especially its oil refining capabilities. By appealing to its dominant energy beneficiary, China increased fuel shipments to the Islamic Republic and is aiding Iran with its refining expansion efforts (Harold and Nader, 2012:11). Assisting Iran has provided the Chinese with an opportunity to expand their foreign investment and a chance to enter Tehran's "good books" for securing future oil supplies (Baker, 2010:19). Since the Chinese are essentially keeping the Iranian energy sector afloat, Molavi suggests that the Sino-Iranian relationship seems to be more vital for Tehran than Beijing (Molavi, 2010:51). By playing on this asymmetrical dependence, Chinese firms have asserted that if there are hindrances that prevent China's Iranian projects from obtaining attractive profits, they will revert to a peripheral position in the country's energy sector (Lee and 
Shalmon, 2007:21).

Despite the seemingly anchored Sino-Iranian economic-energy relationship, major Chinese NECs (National Energy Companies) have been stalling the implementation of agreements in Iran in the face of sanctions. However, there has been no clear indication if the decision to delay the implementation of energy deals is a directive from the Chinese government or based on Chinese NECs' wariness of proceeding with energy plans in a high-risk environment. Harold and Nader suggest that firms are individually weighing up the risks to avoid a Libyan scenario, where analysts forecasted that a democratic Libya would potentially cost China US\$ 18.8 billion in investments (Harold and Nader, 2012:12). While awaiting the outcome of the Obama Administration's deliberation regarding the possibility of sanctioning Chinese firms under the Comprehensive Iran Sanctions, Accountability, and Divestments Act of 2010 (CISADA), China delayed the implementation of an estimated US\$ 40 billion in 2010 investments to revamp Iran's petroleum industry (Salvin, 2011:3). Thus, of the US\$ 40 billion, China, in 2011, had so far only provided less than US\$ 3 billion (Salvin, 2011:3). If a high risk business environment is behind Chinese NECs reluctance to implement decisions it can be assumed that, once Tehran gains a more favourable international status, China is likely to advance the implementation of agreements in order to avoid competition from other countries who may want to reengage with Iran (Harold and Nader, 2012:12).

\section{Geostrategic: countering US hegemony in the Middle East}

In terms of geostrategic reasoning the Islamic Republic is of major importance to China. Iran stands out mainly because it is the largest and most populous Islamic country in the oil abundant Middle East (Jun and Lei, 2010:50). Moreover, due to its strategic location, geographical land mass and human resources, Iran is considered to be a regional power in the Middle East. The Islamic Republic is deemed to be geostrategically imperative because (Jun and Lei, 2010:50): firstly, Iran has a stretching coastline on the North Arabian Sea which dominates the entire eastern side of the Persian Gulf. Secondly, the Islamic Republic has lengthy borders with Iraq, Turkey, Afghanistan and Pakistan. Furthermore, Iran also borders on some of 


\section{AFRICAN \\ EAST-ASIAN \\ AFFAIRS \\ THE CHINA MONITOR}

the remaining republics of the former Soviet Union, namely Armenia, Azerbaijan and Turkmenistan. Lastly, towards the North of Iran, the country also has a coastline on the Caspian Sea and shares borders with states in the Central Asian region.

Taking these geostrategic factors into account and the country's potential as a regional power, in the 1970s Washington considered Iran to be a "strategic pillar" in America's grand strategy for Western Asia (Jun and Lei, 2010:50). However, with the ousting of the Shah in 1979 and the Iranian hostage crisis, the US revised its views of Iran and deduced that the country was to be considered a "strategic threat" (Jun and Lei, 2010:50). Over the years, Washington's aversion towards Tehran has been demonstrated by the numerous unilateral sanctions against the country and statements by American officials which deem the country to be a "pariah" state and part of the "Axis of Evil". As such, the Americans have strategically established an expansive military and naval presence in the Middle East in order to protect their oil investments, to insure regional stability and, most importantly, to serve as a warning to Iran via gunboat diplomacy. Such actions have produced significant changes in geostrategic alliances; this is particularly demonstrated by the strengthened Sino-Iranian relationship.

China perceives that America's policy towards the Middle East and its established military presence serves to bolster the US's dominance in the region (Cooney, 2005:6). Stemming from Beijing's desire for a multi-polar world and its opposition to the US's hegemonic influence in the Arab world, a part of China's foreign policy towards the Middle East is based on opposing American hegemony in the area. Beijing strongly favours multi-polarity because the PRC, "believes that a regional and international environment in which the US is obliged to accept the diversity of political and social systems best serves China's interests" (Garver, Leverett and Leverett, 2012:18). Such thinking could possibly stem from Beijing's anxiety over Washington's ability to control strategic global areas and its potential to cut off energy supplies to China in the event of a military conflict, possibly over Taiwan (Harold and Nader, 2012:2). Additionally, Chinese analysts are concerned with Washington's potential to utilise its hegemonic status to assert control over oil resources that could be used as leverage to coerce major oil consumers, since, "once 
you control the gulf, you control Europe, Japan and China, like holding the tap in your hands." (Jianxin, 2005:5). Thus, oil is more than just a fuel resource, it is a power tool.

However, without any strong historical ties or a longstanding strategic interest in the region, China's mission to "chip away" at American dominance in the Middle East is hampered. As such Beijing has avoided directly challenging the US's hegemonic position. Instead, the PRC is indirectly working towards minimising America's strong influence in the area by supporting or building relationships with regimes that have an aversion towards the US's presence in the Middle East (Cooney, 2005:7). In this regard, Iran is considered to be an ideal partner for China. Aware of the Islamic Republic's emergence as a regional power, geostrategic location, distaste of America's influence in the region and, most importantly, Iran's shared view of a multi-polar world, Beijing has sought to forge sturdy economic, diplomatic and military ties with Tehran to counterbalance US power in the Middle East.

Since American-Gulf alliances have established a security regime that is in line with the US's interests in the Middle East, China has been prompted to pursue substantial military and defence relations with Iran (Cooney, 2005:7). The Chinese strategically reason that assisting Iran with military improvements indirectly counterbalances US dominance in the Persian Gulf (Harold and Nader, 2012:18). Furthermore, there have been suggestions that Beijing may eventually propose to enter into a formal defence relationship with Iran but, due to the negative implications that such an agreement would have on China's relations with the US, the Arab world and Israel, a SinoIranian defence relationship seems unlikely (Harold and Nader, 2012:19). Nevertheless, this does not mean that geopolitical co-operation between China and Iran is stunted. On the contrary, geostrategic collaboration between these two nations can continue to advance, despite the absence of a formal defence agreement (Harold and Nader, 2012:19). Chinese analysts advocate that Beijing's efforts to strengthen ties with Iran could serve as a hedge to prevent Iran from succumbing to American influences in the future. However, China and Iran's diverging interests regarding the US limits the extent of their opposition towards Washington. Unlike Tehran who is almost entirely cut off from the US's economy and has to deal with numerous 
American-led international sanctions, Beijing depends greatly on Washington for its economic growth and the protection of its oil shipments along East Asian sea routes. Thus, China's desire to counter America's dominance in the Middle East is limited by its dependence on favourable trade and investment relations with Washington (Harold and Nader, 2012:21).

In sum, in spite of the imposition of international sanctions against Iran, Sino-Iranian relations have grown considerably. This is particularly demonstrated by the increase in trade between the two countries, as well as their shared interest in expanding relations to encompass non-energy related co-operation and investment. Nevertheless, energy (particularly the export of large amounts of oil to China) remains the cornerstone of this relationship - it is a significant factor that rationalises Beijing's maintenance of ties with the internationally isolated Tehran. However, as a result of a risky Iranian business climate, Chinese NECs have been stalling the implementation of energy agreements with Iranian suppliers. This has led to increased doubts over China's commitment to Iran in the face of Western calls for Beijing to distance itself from a nuclear-aspirant Tehran. Aside from Iran's alluring hydrocarbon assets, the Chinese also acknowledge the significant role that Tehran can play in keeping a check on US influence in the Middle East. Aware of the country's geostrategic position and its regional power status, Beijing has been motivated to forge sturdy ties with Tehran in order to counterbalance US power in the Middle East. However, unlike Iran, Beijing's economic dependence on Washington limits it from significantly minimising the US's dominance in the Middle East. Although Sino-Iranian relations have grown and strengthened over the years, diplomatic pressure placed on China to contribute to isolating Tehran may have influenced the Chinese to reassess their economic-energy interests in Iran. Nevertheless, even though the Islamic Republic is regarded as just another market and energy source for China, Beijing cannot be easily swayed in its decision to engage with Iran as it has come to play a vital role in shaping Chinese interest in the Middle East. 
AFRICAN

EAST-ASIAN

AFFAIRS

THE CHINA MONITOR

\section{Endnotes}

1. The shared Silk Road heritage links China, Iran and the post-Soviet states of Central Asia, and serves as a historical basis for present day co-operation. Gentry, "The Dragon and The Magi: Burgeoning Sino-Iranian Relations in The $21^{\text {st }}$ Century," p. 111.

\section{Bibliography}

Baker, M. 2010. Beyond Oil? Chinese National Interests and the Sino-Iranian Relationship. Unpublished Masters Thesis. Washington: Georgetown University. [Online]. Available: http://repository.library.georgetown.edu/ bitstream/handle/10822/553441/bakermelinda.pdf?sequence $=1 \quad[25$ June 2012].

BBC News, 2014. China to Double Iranian Investment [Online]. Available: http:// www.bbc.com/news/business-30075807 [30 May 2015].

Budike, C.U.J. 2010. Securing China's Oil Supply from the Persian Gulf: The Case of Iran and Saudi Arabia. Unpublished Masters Thesis. Amsterdam: University of Amsterdam. [Online]. Available: http://epa.iias.asia/files/ Jurgen\%20Budike_Securing\%20China's\%20Oil\%20Supply\%20From\% 20the\%20Persian\%20Gulf.pdf [17 July 2012].

Dickey, L. and Ighani, H. 2014. Iran Looks East, China Pivots West [Online]. Available: http://thediplomat.com/2014/08/iran-looks-east-china-pivots-west/ [30 May 2015]

Calabrese, J. 2006. China and Iran: Mismatched Partners. The Jamestown Foundation [Online]. Available: http://www.jamestown.org/docs/JamestownChinaIranMismatch.pdf [04 July 2012].

Chubin, S. 2010. Iran and China: Political Partners or Strategic Allies, China's Growing Role in the Middle East: Implications for the Region and Beyond 
AFRICAN

[Online]. Available: http://cftni.org/full-monograph-chinas-growing-role-inme.pdf [05 February 2012].

Cooney, J. 2005. Chinese Oil Dependence: Opportunities and Challenges, Pennsylvania: U.S. Army War College [Online]. Available: http:// www.dtic.mil/cgi-bin/GetTRDoc?AD=ADA432502 [08 June 2012].

Coskun, B.B. 2009. Global Energy Geopolitics and Iran. Uluslararası Illişkiler, 5 (20): 179-201.

Davis, M. D., Lecky,J., Froscher,T., Chen,D., Kerevel, A., and Schlaikjer, S. 2012. China-Iran: A Limited Partnership. U.S.-China Economic and Security Review Commission [Online]. Available: http://missilethreat.wpengine.netdna -cdn.com/wp-content/uploads/2012/12/USCC_China-Iran-Report-Nov-28.pdf [12 March 2013].

Dorraj, M. and Currier, C. L. 2008. Lubricated with Oil: Iran-China Relations in a Changing World. Middle East Policy, 15(2): 66-80.

Douglas, J., Nelson, M., Schwartz, K. 2006. Fuelling the Dragon's Flame: How China's Energy Demand Affects its Relationships in the Middle Eas [Online]. Available: 2012http://origin.www.uscc.gov/sites/default/files/Research/ fueling\%20the \%20dragons\%20flame.pdf [16 July 2012].

Farrar-Wellman, A. and Frasco, R. China-Iran Foreign Relations [Online]. Available: http://www.irantracker.org/foreign-relations/china-iran-foreignrelations [06 December 2012].

Fite, B. 2012. U.S. and Iranian Strategic Competition: The Impact of China and Russia. [Online]. Available: http://csis.org/files/publication/ REPORT_Iran_Chapter_X_China_and_Russia_Final_Revision2212.pdf [15 June 2012].

Garver, J., Leverett, F., Hillary, M.L. 2010. Moving (Slightly) Closer to Iran: China's Shifting Calculus for Managing its "Persian Gulf Dilemma."Asia Pacific Policy Papers Series [Online]. Available: http:// 
AFRICAN

EAST-ASIAN

AFFAIRS

www.reischauercenter.org/en/wp-content/uploads/2012/05/ moving_slightly_closer.pdf [24 June 2012].

Gentry, J. B. 2005. The Dragon and The Magi: Burgeoning Sino-Iranian Relations in The $21^{\text {st }}$ Century. The China and Eurasia Forum Quarterly, (3)3: 111-125.

Harold, S. and Nader, A. 2012 China and Iran: Economic, Political and Military Relations. [Online]. Available: http://www.rand.org/content/dam/rand/pubs/ occasional_papers/2012/RAND_OP351.pdf [15 June 2012].

Hongtu, Z. 2010. China's Energy Interest and Security in the Middle East, China's Growing Role in the Middle East: Implications for the Region and Beyond [Online]. Available: http://cftni.org/full-monograph-chinas-growing-role-inme.pdf [05 February 2013].

Jianxin, Z. 2005. Oil Security Reshapes China's Foreign Policy. Centre on China's Transnational Relations: The Hong Kong University of Science and Technology, 9: 1-12.

Jun, L., and Lei., W. 2010. Key Issues in China-Iran Relations. Journal of Middle Eastern and Islamic Studies (in Asia), 4(1):40-57.

Kredo,A. 2014. China Becomes Iran's Largest Trade Partner [Online]. Available: http://freebeacon.com/national-security/china-becomes-irans-largest-tradepartner/ [30 May 2015].

Lai, H.H. 2007. China's Oil Diplomacy: is it a global security threat? Third World Quarterly, 28 (3):519-537.

Lee, H., and Shalmon, D. 2007. Searching for Oil: China's Oil Initiatives in the Middle East, Belfer Centre for Science and International Affairs. [Online]. Available: $\quad$ http://belfercenter.ksg.harvard.edu/files/china\%20oil\%20h\% 20lee\%202007.pdf [16 July 2012].

Mackenzie, P. 2010. A Closer Look at China-Iran Relations, CNA Roundtable Discussion: China's Relations with Iran . [Online]. Available: http:// 
AFRICAN

www.cna.org/sites/default/files/research/d0023622\%20a\%20closer\% 20look\%20at\%20china-iran\%20relations.pdf [05 March 2012].

Molavi, A. 2010. The New Silk Road, "Chindia," and The Geo-Economic Ties that Bind the Middle East and Asia, in Wakefield, B. and Levenstein, S. L., (eds.). China and the Persian Gulf. Washington: Woodrow Wilson International Centre for Scholars. 45-54.

Morris, A. 2012. From Silk to Sanctions and Back Again: Contemporary SinoIranian Economic Relations. Al Nakhlah: Online Journal on Southwest Asian and Islamic Civilization . Medford: Tufts University. 1-8.

Salvin, B. 2011. Iran turns to China, Barter to Survive Sanctions, Atlantic Council: Iran Task Force [Online]. Available: http://www.acus.org/files/ publication_pdfs/403/111011_ACUS_IranChina.PDF [15 June 2012].

Swaine, M.D. 2010. Beijing's Tightrope Walk on Iran. China Leadership Monitor, 33: $1-19$.

Vakil, S. 2006. Iran: Balancing East against West. The Washington Quarterly, 29(4): 51-65. 
AFRICAN

EAST-ASIAN

"Enduring silk ties"

AFFAIRS

THE CHINA MONITOR

(C) Centre for Chinese Studies, Stellenbosch University All Rights Reserved. 